\title{
CHANGES IN WOODLAND COVER IN THE KARVINÁ DISTRICT FROM THE SECOND HALF OF THE 18th CENTURY TO THE BEGINNING OF THE 21st CENTURY
}

\author{
RENATA POPELKOVÁ
}

Department of Physical Geography and Geoecology, University of Ostrava, Chittussiho 10, 71000 Ostrava-Slezská Ostrava, Czech Republic; e-mail: Renata.Popelkova@osu.cz

\begin{abstract}
Popelková R.: Changes in woodland cover in the Karviná district from the second half of the 18th century to the beginning of the 21st century. Ekológia (Bratislava), Vol. 37, No. 2, p. 134-151, 2018.

This study analyses the changes in woodland cover from the mid-18th century to the turn of the 21st century in a distinctive region of the Czech Republic - the Karviná district. This region has been substantially affected by the process of industrialisation during the 19th and 20th centuries, which transformed a formerly agricultural landscape into a landscape heavily impacted by underground coal mining and related landscape processes. The occurrence of woodland cover in the Karviná district was determined from historical military maps (second half of the 18th century, first half of the 19th century, second half of the 19th century, first half of the 20th century) and from a colour orthophoto (2017) verified with reference to a contemporary map. The article interprets the occurrence of woodland cover depicted in the abovementioned sources and presents an interpretative key. The vectorisation of the woodland cover and the analysis of temporal-spatial changes in woodland cover were conducted using ArcGIS 10 software.
\end{abstract}

Key words: industrialization, afforestation, deforestation, military mapping, orthophoto.

\section{Introduction}

The contemporary landscape is a result of the action of both natural and anthropogenic factors. Human activity has created a wide range of different landscape types, from natural landscapes through cultural landscapes to anthropogenically transformed landscapes (Van der Zee, 1999). Humans tend to cause short-term, dynamic landscape changes. Anthropogenic effects occur most commonly in areas that are intensively exploited by humans (e.g. for mining, intensive agriculture or forestry) or that are adapted by humans for their own use (e.g. new built-up areas). The social and economic changes that began in Europe in the late 18th century (and subsequently also occurred in other continents) caused a marked acceleration of landscape changes.

Landscape changes can be understood as a modification of landscape structure over the course of time (Leitao et al., 2006). A quantitative analysis of landscape change can be conducted by analysing temporal-spatial changes in land use or land cover; valuable sources of information are historical maps (Hersperger, Bürgi, 2009) and aerial/satellite image time 
series (Otahel, Feranec, 1999; Kučera, Guth, 1999; Cooper, Loftus, 1998; Plieninger, 2006; Feranec et al., 2007; Sleeter et al., 2013; Sexton et al., 2013 etc.).

The land-cover change is a main component of global change. Board land change patterns and processes and their main driving forces were examined in Central and Eastern Europe during distinct periods of the past 250 years (Munteanu et al., 2014). A total of 66 papers that were based on spatially explicit data (historic maps, aerial photographs and satellite imagery) and that captured gradual changes since the peak of the Austro-Hungarian Empire up to the accession to the European Union of most of the formerly socialist countries in the study region are analysed. The study is focused on agricultural (agricultural expansion, abandonment) and forest (afforestation, deforestation). In terms of the drivers, institutional and economic factors were most influential in shaping deforestation and agricultural expansion, whilst socio-demographics and institutional shifts were the key drivers of land abandonment. The study highlights the drastic effects that socio-economic and institutional changes can have on land-use and land-cover change and the value of longitudinal studies of land change to uncover these effects. Plieninger et al. (2016) analysed 144 studies that identify the proximate and underlying drivers of landscape change across Europe. They found out that land abandonment is the most frequent driver of landscape change in Europe. In some regions of the world such as the Northern Hemisphere, the abandonment of agricultural land is one of the most widespread forms of land use change. In general, abandonment is followed by colonisation by herbaceous and woody plants. Rühl et al. (2015) analysed afforestation in large areas of southern Italy. Selby et al. (2005) investigated how farmers and rural advisors perceive forests, forestry and afforestation in the context of rural development in three Finnish regions. Abandonment of agricultural land in Europe has been investigated by Lasanta et al. (2017). A general view of the extent of abandoned land, the stages of abandonment and the drivers that manage this process in Europe is presented. Lieskovský et al. (2015) analysed the extent and driving forces of the abandonment of traditional agricultural landscape in Slovakia. One of their findings is that $50 \%$ of Slovak traditional agricultural landscapes are partly abandoned or abandoned. Hersperger and Bürgi (2009) quantified the importance of driving forces of landscape change in five municipalities near Zurich in Switzerland from the 1930 s to the beginning of the 21 st century. Their study is mostly focused on urbanisation and agricultural intensification. Expansion/intensification of forestry using aerial photos from the mid-20th century was observed on two sites in Spain (Plieninger, 2006). The main goal of this study is to provide quantitative information on loss, fragmentation and alteration of holm oak. There was initially a marked decrease in the area of woodland, followed (from the 1980s onwards) by an increase. Plieninger and Bieling (2012) focused on dehesa (it is multifunctional type of agroforestry) landscapes in the part of Spain. Essex and Williams (1992) studied intensive afforestation on Dartmoor (England) from the first half of the 20th century and evaluated its ecological effects.

The research presented in this article focuses on changes in woodland cover in the Karviná district (Czech Republic) and identifies processes of afforestation and deforestation. It characterises the temporal-spatial changes in the distribution of woodland cover between selected points in time, tracing the two abovementioned processes during the intervening periods. Details of preserved original woodlands are also given. The processes of afforestation 
and deforestation were traced based on the data that captured temporal-spatial changes in woodland cover for a lengthy period of time, from the mid-18th century to the beginning of the 21st century. The multi-temporal analysis was based on the historical military maps (second half of the 18th century, first half of the 19th century, second half of the 19th century and first half of the 20th century) and from a colour orthophoto (2017) verified with reference to a contemporary map.

\section{Study area}

The Karviná district (Czech: okres Karviná) is situated in the north-eastern part of the Moravian-Silesian Region (in the easternmost part of the Czech Republic). The district was created in 1960 during a reorganisation of territorial administrative units within Czechoslovakia. It covers an area of $356 \mathrm{~km}^{2}$ and consists of 17 municipalities, of which 7 have city status. The delineation of the study area is shown in Fig. 1.

The study area consists of flat or gently rolling terrain, without major hills/mountains or terrain breaklines. The land relief falls into two distinct parts; the divide runs approximately along the Havírov-Chotěbuz rail line. The larger northern part belongs to the Ostrava basin. The terrain here is slightly rolling, with numerous bodies of water; there are extensive underground mine workings, and in places, the ground has experienced substantial subsidence. The coal-bearing sediments of the Ostrava basin lie below tertiary and quaternary layers. The smaller southern part of the study area consists of low hills; here the nature of the terrain is more similar to the Beskydy mountains (which lie to the south). There is more variation in elevation in this southern part of the study area, and it is less affected by human activity, with numerous natural structures.

The hydrological system of the Karviná district forms part of the Odra River drainage basin, which belongs to the Baltic Sea catchment basin. The area covered by standing and flowing water bodies is larger than the national average. Two of the main rivers in the district delineate the border with Poland (the Olše River in the north and

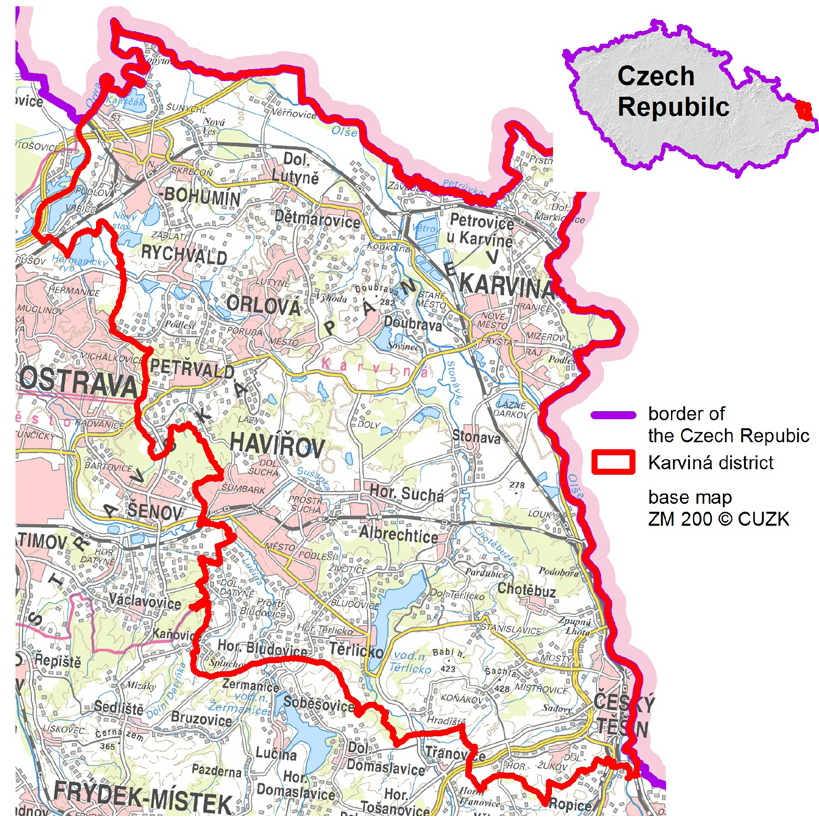

Fig. 1. Delineation of the study area. the Odra River in the west). At the northernmost point in the district is the confluence of these two rivers; the Odra then leaves the territory of the Czech Republic and flows northwards through Poland. There are numerous standing bodies of water in the district, both large and small.

The Karviná district has experienced substantial temporalspatial landscape changes, many of which are immediately visible to the observer. Underground coal mining and the development of heavy industry have had a major effect on changing woodland cover in the Karviná district; part of the OstravaKarviná coalfield covers around one-third of the district's total area (Mulková et al., 2016). Originally a developed agricultural region, the study area began to undergo a marked transformation following the discovery of coal in Karviná (1776). During the 19th century, the region became industrialised, with many coal mines and related industrial facilities established. The massive 
development of heavy industry following the communist takeover in 1948 further contributed to the transformation of the region, bringing major investments in coal mining together with an influx of new workers and the construction of extensive new housing schemes (Havírov, Karviná, Orlová), accompanied by the devastation of large areas of the landscape and some original buildings. During the 1980s, the coal mining industry began to stagnate, as the volumes of coal extracted from the mines in the district decreased because of the progressive exhaustion of the easily workable deposits. The early 1990s brought a rapid restructuring of the economy on a nationwide scale, and heavy industry went into rapid decline. In the Karviná district, this change was manifested in the closure of coal mines that were no longer economically viable (Popelka et al., 2016).

\section{Materials}

The sources that help us learn about past land cover/land use are rather wide. Primarily, archive aerial photographs, old maps and cadastral maps belong to such sources. The historical data for the study was taken from the analysis of maps produced for military purposes from the 18th to the 20th century; the current data was taken from a colour orthophoto (2017) verified with reference to a contemporary map.

The first systematic mapping of the Bohemian Crown Lands (i.e. the provinces of Bohemia, Moravia and Habsburg Silesia, which together make up the territory of today's Czech Republic) took place in the second half of the 18th century, in connection with the Wars of the Austrian Succession. In 1763, following the Habsburg Monarchy's military failure in the Seven Years' War, Empress Maria Theresa had military maps drawn up for all the Habsburg provinces. The first complete series of maps - known as the 'military maps' or the 'Josephine maps' after Emperor Joseph II - was completed in 1785 (Semotanová, 2001). The majority of the Monarchy's territory was mapped at a relatively large scale (1:28,800), which was known as the 'simple scale' (Boguszak, Císař, 1961). The province of Austrian Silesia (of which today's Karviná district formed a part) was mapped relatively early, in 1763, because of its strategic location on the border with Prussia. The Silesian maps consisted of 40 sections and covered the Duchies of Teschen (now Těšín/ Cieszyn), Troppau (Opava), Jägerndorf (Krnov) and Neisse (Nysa). The original maps were inadequate in terms of both planimetry and topography, so in 1780, a total of 30 sections were remapped, and the remaining 10 sections were corrected. Unlike most of the other military maps, the scale used for the new maps was 1:30,746 (Kuchař, 1967).

This first series of military maps is a valuable source of comparative data because it covers the whole of the Bohemian Crown Lands, and the scale of the maps makes them ideal for studying landscape changes. However, the planimetric content of the maps is problematic; the surveyors did not use a single trigonometric network, and different methods were used in the different provinces (Crown Lands). The resulting planimetric deformations make these maps unsuitable for purposes of precise quantitative analysis - although the first military maps are more precise than the previous maps drawn up by Johann Christoph Müller (Boguszak, Císař, 1961; Mikšovský, Zimová, 2006). However, despite these problems, most researchers, nevertheless, consider the first military maps to be an important source of information on the landscape of the Bohemian Crown Lands during the final third of the 18th century (Hauserová, Poláková, 2015). The original hand-drawn sections of the first military maps are held at the Österreichisches Staatsarchiv in Vienna; copies of the maps of the Bohemian Crown Lands are available at the National Archives (Národní archiv) in Prague and also at the Geoinformatics Laboratory of the J. E. Purkyně University in Ústí nad Labem, where the first, second and third series of military maps have been digitalised.

By the turn of the 19th century, the first military maps were no longer able to cope with increased demands on their level of accuracy. In 1806, Emperor Franz I, therefore, ordered an astronomic and geodetic survey to be conducted in order that a trigonometric network could be built (Semotanová, 2001). This enabled cartographers to produce very detailed cadastral maps at a scale of 1:2,880, followed by a second series of military maps $(1: 28,800)$, known as the 'Franz maps'. The second series of military maps covering the Bohemian Crown Lands were not produced until the 1830s and 1840s; they were based on the cadastral trigonometric networks. The provinces (Crown Lands) of Moravia and Austrian Silesia were mapped in 1836-1840 (Boguszak, Císař, 1961; Čada, 2006). This second series of military maps is an excellent source of information for tracing landscape changes, for a number of reasons. Their scale is ideal, and the planimetric content of the maps is precise. In addition, the second series of military maps (like the so-called 'imperial prints' of the stable cadastral maps) capture the landscape at a crucial turning point - a time when the modernisation processes associated with the Industrial Revolution and the transformation of society were becoming particularly intense and widespread.

The military defeat of the Habsburg forces in the Austro-Prussian War (1866) ultimately led to the production of a third series of military maps, which were updated and amended (Boguszak, Císař, 1961). Austrian Silesia and 
eastern Moravia were remapped in 1876, followed by the remaining parts of the Bohemian Crown Lands (completed in 1879). The maps featured the so-called 'simple scale' that used the decimal system (in anticipation of the expected introduction of the metric system) at a scale of 1:25,000; a scale of 1:12,500 was used for areas of particular military interest. The third series of military maps was based on trigonometric points taken from the rectilinear cadastral grid. The graphic planimetric basis for the maps was a reduced-size version of the cadastral maps (reduced from 1:2,880 to $1: 25,000)$. The original topographic sections were produced with 11 colours; the copies were either coloured or (for larger print runs) black and white (Boguszak, Císař, 1961).

This third series of military maps remained the official maps of Czechoslovakia until after the Second World War; they were replaced by new military topographic maps in 1956. The third series of military maps enable the identification of landscape features (commensurate with their scale) for purposes of comparison (Sklenička, 2003).

The surveying for the new topographic maps - which are still used today - was conducted between 1953 and 1957. A total 1736 military topographic map sheets were produced at a scale of 1:25,000. The maps used symbols that had been universally introduced throughout the Warsaw Pact countries. These military topographic maps were followed by topographic maps at smaller scales, which were used as the standard official maps.

To determine the occurrence of woodland cover today, the most recent available orthophoto (2017) was used. In order to maximise comparability with the data from the other maps, data from ZABAGED and the current $1: 25$ 000 basic map were used to verify all vectorised areas.

\section{Methods}

The relevant sheets from the first, second and third military map series were acquired in digital form from the Geoinformatics Laboratory of J. E. Purkyně University in Ústí nad Labem. The topographic maps from the 1950s were digitalised by scanning. The individual sheets for each of the selected years were then cropped, combined into a single image, and georeferenced. The maps were transformed into the S-JTSK coordinate system via ArcGIS 10 software, using identical ground control points. When georeferencing old maps, it is best to use topographic elements as ground control points, because their position remains stable over the course of time; naturally, if using current reference data, it is essential to select topographic elements that still exist today. These include road junctions, church towers or other buildings that are still standing, pond floodgates and (if no other suitable points exist) river confluences. If older (i.e. non-current) reference data are used, it is easier to identify suitable ground control points.

Georeferencing the first series of military maps is highly problematic. In view of the method that was used to create the maps, the transformation into the S-JTSK system is only approximate. It was also difficult to find suitable ground control points for these maps. The officers from the military surveying authority paid considerable attention to recording roads, rivers and streams and also land use and building use. Road junctions (and occasionally buildings) were used as the ground control points. Despite the problems with georeferencing and accuracy, the first series of military maps represents a rare source of information on the 18th-century landscape, particularly because of their scale and level of detail. For this reason, these maps were included in the analysis of temporalspatial changes in woodland cover. When georeferencing the maps, affine transformations (first-order polynomial transformations) were used. Currently, the military maps from the second series are available via the map server of the national geoportal INSPIRE. The accuracy of the transformation of the previously georeferenced map sheets from this second series was verified by overlaying them on the same maps displayed via the map server.

It was not necessary to carry out any adjustments to the 2017 orthophoto. It was displayed via the map services of the Czech Surveying and Land Registry Authority (Český úřad zeměměřičský a katastrální, ČÚZK). The orthophoto from the ČÚZK ArcGIS server was displayed using ArcGIS software in the S-JTSK coordinate system.

The occurrence of woodland cover in the 18 th, 19 th and 20 th centuries was determined from the transformed historical maps. The symbol for woodlands in the third series of military maps (at 1:25,000 scale) is not always clearly distinguishable on the maps. For this reason, the location of the woodlands was verified using the special 1:75,000 military maps from the third series, which clearly mark woodland areas in green. The special maps were displayed in ArcGIS via the WMS service of the public administration portal. When determining the occurrence of woodland cover from the military topographic maps, an orthophoto from the 1950s was used to verify the data and provide clarification in disputed cases.

In order to ensure that the 21st-century data are as recent as possible, the current occurrence of woodland cover was determined via a visual photointerpretation of the most recent orthophoto (2017). The maps were generalised at the time of production, whereas the generalisation of the orthophoto to $1: 25,000$ had to be carried out during 
vectorisation. The occurrence of woodland cover was verified using ZABAGED data and the current 1:25,000 basic map, displayed via the map services of the Czech Surveying and Land Registry Authority (WMS - ZABAGED and WMS - ZM 25). The minimum vectorised polygon $\left(1700 \mathrm{~m}^{2}\right)$ was derived from the minimum size of the vectorised polygons from the historical maps, taking into account the scale (1:25,000). Vectorisation (using ArcGIS software) took place whilst determining woodland cover occurrence from the maps.

Vector layers were created for the woodland cover at each individual analysed point in time. On the basis of the processes under investigation (deforestation and afforestation), the temporal-spatial changes in woodland cover in the Karviná district were determined.

These processes can be defined broadly, including long-term natural processes (geomorphological processes, climate change), difficult-to-predict processes (landscape disturbances) and cultural processes (Marcucci, 2000). The temporal-spatial changes in woodland cover occurrence can be used to characterise the processes of afforestation and deforestation. In the Biopress methodology (2016), the process of afforestation is described as the transformation of agricultural land and other areas (urbanised, natural, semi-natural and aquatic) to natural and semi-natural woodland. Deforestation is the opposite process; woodland cover is lost, transformed into another type of land cover. When evaluating afforestation and deforestation, it is of course essential to take into account the duration of the investigated periods, which depends on the availability of data sources. The second investigated period (1836-1876) is the shortest, at 40 years. The other investigated periods are approximately the same length: the first (1780-1836) covers 56 years, the third (1876-1952) covers 76 years and the fourth (1952-2017) covers 65 years.

\section{Interpretation of woodland cover based on the analysed data sources}

The process of interpretation is based on the gradual analytical acquisition of the necessary information from the data source. The interpretation of the data sources (i.e. the military maps and the orthophoto) takes place in three basic phases:

1. Determination of depicted entities based on specific features such as shape, colour, size and structure;

2. Identification of individual entities and their selection on the basis of preselected criteria (interpretative key);

3. Interpretation of the facts determined via the first two phases.

The interpretation of the data from the maps proved to be more difficult than expected. In order to precisely determine the occurrence of woodland cover from the maps, the available legends for the historical maps were studied, as was literature giving information on the depiction of woodland in the maps. On the basis of the map legends and the literature and also on previous experience of deducing landscape structure from historical maps and aerial photographs, the interpretation key shown in Appendix 1 was created. All elements in the key are displayed at a scale of $1: 25,000$.

The first series of military maps depicted woodland areas in grey-green with a schematic symbol representing a tree (Brůna et al., 2003). It can be expected that the density of the tree symbols corresponded with the nature of the woodland area in question, particularly with respect to its degree of crown closure. Unlike the more recent maps, the first series does not mark clear boundaries between the woodland areas and the other parts of the landscape. The gradual transition from woodland to scattered vegetation or grassland is more accurately representative of the real situation on the ground, but it makes interpretation more difficult and hinders the process of vectorisation (in which it is necessary to delineate the boundaries of spaces). The tree symbols used in the first series of maps enabled the cartographers to capture various degrees of tree density and height, as well as other information (e.g. boggy woodlands). Another advantage of this method is that in hillier areas, the trees are better visible against the background of the dark hatching that represents the terrain relief (Brůna, Křováková, 2006). Larger areas of woodland are named (in black lettering).

The second series of military maps no longer use the tree symbols. Woodland cover is represented by grey-green or brown-green areas with darker borders. In the case of larger areas of woodland, a coniferous or deciduous tree symbol is used to denote the predominant type of vegetation. The boundaries of the woodland areas are easier to interpret than in the first series of military maps, but problems occur in areas of higher elevation, especially with more steeply sloping terrain. The terrain relief is represented by hatching; the increasing thickness of the hatching lines represents a steeper gradient. However, on the steepest slopes, the hatching lines almost run into each other, resulting in a relatively dark surface - sometimes almost solid black - against which it is not possible to identify any other map markings (Brůna, Křováková, 2006). The interpretation of woodland cover can also be problematic in the darker map sheets. Similar to the first series of military maps, the second series also gives the names of larger areas of woodland (again in black), but these are illegible in locations with steep gradients. 
The third series of military maps uses grey-green colouring to mark woodland areas, although the use of tree symbols is less prominent. A single coniferous or deciduous tree located in the centre of the woodland area indicates the predominant type of vegetation, but this symbol only appears rarely. In some cases, the symbol is less easily visible, so identifying woodlands is sometimes more difficult than in the maps from the second series. The third series also uses thick hatching to represent steep slopes, which likewise causes problems of interpretation. For this reason, it is advisable to use the special maps from the third military series in order to verify the data. These special maps depict woodlands in bright green, which (besides black and white) is the only colour on the maps, making it very easy to identify woodland areas. The special maps use a scale of 1:75,000, but (especially in the case of larger woodland areas) they offer very valuable data for verifying the interpretations of the 1:25,000 maps from the third series. As in the previous series, the maps in the third series give the names of the larger woodland areas (again in black lettering); in some cases, the Czech name is also given alongside the German name.

The military topographic maps from the 1950s depict woodland areas as bright green surfaces. In the case of the larger woodland areas, the type of vegetation is denoted by a coniferous or deciduous tree (or both in the case of mixed woodlands). In some cases, a more precise identification of the tree species is given (e.g. spruce, oak), and for some woodlands, data is given on the average tree height, trunk diameter or tree spacing.

The visual interpretation of aerial photographs enables us to use direct interpretative features (shape, shadow, size, colour, tone, texture, structure, etc.) and indirect clues (based on our knowledge of the interrelations amongst the direct features) to determine and describe the appearance and properties of entities and phenomena depicted on images (Čapek, 1978; Antrop, Eetvelde, 2000). Certain types of vegetation, bodies of water, rocks and so on reflect solar energy in different ways, giving the electromagnetic radiation a different and clearly distinguishable character. Woodlands are quite easy to distinguish on the colour orthophoto; they are dark green areas, mostly with clearly visible tree crowns (and sometimes entire trees).

\section{Results}

In the pre-industrial era, the Duchy of Teschen (now Těšín/Cieszyn) was a region with a relatively low degree of urbanisation (in comparison with other regions of Silesia) and with very diverse land use because of the diversity of geographical conditions. The lowland parts of the Duchy (including the Karviná district) were agricultural, whereas the economy in the Beskydy mountains and their foothills was based primarily on forestry (Pitronová, 1968; Korbelářová, 2005). The development of agriculture and forestry was determined by natural conditions. The Karviná region is largely flat, with minimal variation in elevation. There is sufficient precipitation (with the highest levels in the summer months) and favourable temperatures for agriculture (comparable with the fertile agricultural region of Haná in Central Moravia). The soils in the Karviná region are predominantly of lower quality, mainly podzols and also clay and rendzina soils. The soil conditions are thus less favourable, but the favourable temperature conditions and the use of fertilisers make it possible to grow more demanding crops. In view of the soil quality, the most commonly cultivated crop types are potato/barley and potato/wheat (Havrlant, 1964).

In the pre-industrial era, the Karviná region was primarily an area of arable land. According to the stable cadastre map from the 1830s, arable land occupied more than twothirds of the area of the current Karviná district. Agricultural exploitation was intensive. According to information collected by valuers for the stable cadastre, the local farmers grew common types of grain, potatoes and sugar beet, cabbages and clover. Data on livestock also confirm that agriculture was intensive. There were relatively large numbers of horses, which was connected with the extensive presence of arable farming. The number of cattle was not higher than the average in neighbouring regions. Sheep farming was also highly developed 
T a ble 1. Total area of forests taken from the source data and their percentage share of the total area of the Karviná district.

\begin{tabular}{|l|c|c|c|}
\hline Data source & Year & Woodland areas (ha) & $\begin{array}{c}\text { Woodland areas } \\
\text { (\% of total area) }\end{array}$ \\
\hline First military mapping & 1780 & 6817.87 & 19.14 \\
\hline Second military mapping & 1836 & 5416.36 & 15.20 \\
\hline Third military mapping & 1876 & 4904.84 & 13.77 \\
\hline topographic military map & 1952 & 4353.57 & 12.22 \\
\hline orthophoto & 2017 & 7933.05 & 22.27 \\
\hline
\end{tabular}

until the mid-19th century; sheep were bred for wool on the estates of the local nobility (Popelka et al., 2016).

Woodlands represented an important component in the landscape of the Karviná region. The development of woodlands was influenced not only by natural factors but also - indeed primarily - by human activity. The first existing Silesian cadastre (the so-called Caroline cadastre, compiled in the 1720s) contains data on the extent and type of woodlands in the province. However, the data for woodlands is heavily understated because landowners were keen to avoid paying higher taxes. According to the Caroline cadastre, the main woodland species in the Karvina region were beech, oak, alder, fir and spruce (Nožička 1956). The first reliable data on the extent of woodland areas in the 18th century can be gained by analysing the first series of military maps. This analysis shows that there were just less than ,6818 ha of woodlands in the territory of today's Karviná district, that is, $19.14 \%$ of its total area (Table 1 ). As early as the 18 th century, the woodlands were already highly dispersed, scattered over the entire area of the district.

Even before the onset of industrialisation, there was a relatively substantial decrease in the extent of woodland areas in the study area. On the basis of an analysis of the military maps from the second series, it can be stated that by the early 1840s, the total area of woodlands in the study area had decreased to approximately 5,416 ha (i.e. $15.2 \%$ of the total area). This process of deforestation affected $11.8 \%$ of the total area, counterbalancing the afforestation process that was also taking place at the same time (which affected just less than $8 \%$ of the area). The predominance of deforestation revealed by the data corresponds with available information on the loss of woodlands in areas with developed agriculture during the first half of the 19th century: at the outset of the industrialisation process, most woodlands in these areas were relatively long established and consisted mainly of the indigenous mixed populations, with particularly notable populations of beech, oak, alder, fir and, to a lesser extent, spruce (Tichý, 1968). The analysis of species distribution based on the second series of military maps shows that this was also the case in the study area. The majority of woodland was mixed. Coniferous woodlands made up $15 \%$ of the total woodland area, and deciduous woodlands were just $4 \%$. However, more than a quarter of the woodland areas marked on the maps (mainly smaller areas of woodland) do not contain any tree symbols. The most likely reason for the decrease in woodland areas was the economic boom that followed the Napoleonic Wars; estate-owners took advantage of the boom to intensify their agricultural production by turning meadows, pastureland, woodland, ponds and unproductive land into arable land (Rodan, 2008: 64). 
This trend was accentuated by the industrialisation process. Woodlands were not only cleared to meet growing demand for wood; another factor was damage caused to trees (especially conifers) by industrial air pollution. Other factors in the decline of woodland areas included the development of the mining industry and the increasingly intense process of urbanisation, as well as the need for new agricultural land. According to the data yielded from the analysis of the third series of military maps, the area of woodlands in the Karviná district had fallen to approximately 4,905 ha (13.77\% of the study area) since the previous maps, and the process of deforestation during this period had affected $4.5 \%$ of the study area. During the period between the second and third military map series, a large area of woodland had become agricultural land. In terms of species distribution, fir trees were in the most precarious position; in the final third of the 19th century, the fir populations in the Ostrava-Karviná coalfield were wiped out by industrial air pollution (Myška, 1989; Popelka et al., 2016). It is not possible to adequately evaluate the species composition of the woodlands based on the analysis of the third military map series, as the symbols for coniferous and deciduous trees occur only occasionally on the maps.

Until the mid-20th century, deforestation - as a result of the factors described above was one of the most significant landscape formation processes not only in the Karviná district but throughout the entire Ostrava-Karviná coalfield. Woodlands most frequently became agricultural land - a mosaic of fields, meadows and permacultures - or they were abandoned and became overgrown with self-sowing trees, scrub and grass (Popelka et al., 2016).

By the mid-20th century, the area of woodlands in the Karviná district reached a historical minimum. The analysis of the topographic military map shows that woodlands in the study area covered just less than 4,354 ha $(12.22 \%$ of the total area); the process of deforestation affected $4.65 \%$ of the total area during the intervening period. The Karviná district also began to experience widespread mine subsidence, with devastating effects at ground level and the formation of submerged (flooded) ground subsidences (Drlík, 1962; Mareš et al., 1975; Smolík, 1984). By the middle of the 20th century, most of the original indigenous woodlands had disappeared from the landscape and been replaced by artificial plantings. The species composition of the woodlands had also shifted since the mid-19th century. The original fir populations had disappeared entirely and were replaced by spruce. It is easier to identify the species composition of the woodlands from the topographic military maps than from the previous military maps, because most of the woodland areas are marked with the symbols for coniferous or deciduous trees. Almost two-thirds of the woodlands were coniferous, more than one-tenth were deciduous, and less than one-tenth were mixed. Some woodland areas - mainly small in size - were not marked with a symbol showing the predominant type of tree. The most commonly marked species in the maps is spruce (as has been mentioned above), with pine less commonly represented; the most common deciduous species are oak and beech.

The subsequent increase in the area of woodland in the Karviná district was due primarily to two processes: the recultivation of the landscape following the closure of coal mines and the process of deagrarianisation resulting from the collapse of the socialist agricultural planning system.

Research into forestry as a means of recultivating coal mine spoil tips was conducted in the Ostrava-Karviná coalfield from the early 1960s, although pilot projects had already 
been launched in the late 1950s (Smolík, 1981). From the late 1950s to 1966, the first 1,710 ha of land was remediated or recultivated in the Ostrava-Karviná coalfield as part of efforts to reduce the environmental impact of coal mining; of this, 460 ha were recultivated by tree plantings (Popelka, 2013). After 1967, the area of remediated or recultivated land decreased temporarily because of the application of 1966 legislation on the protection of agricultural land; the new legislation placed much more stringent demands on recultivation and led to the introduction of new, more effective recultivation methods. For this reason, between 1967 and 1972 only approximately 263 ha of abandoned land in the Karviná district was recultivated, 56.9 ha of it via forestry (Popelka, 2013). In terms of species, recultivation used mainly more resilient deciduous trees - especially ash, sycamore, red oak, common oak and elm (Smolík, 1981). During the 1970s and 1980s, priority was given to agricultural recultivation (in line with Act no. 125/1976 on the protection of agricultural land); after negative past experiences, the legislation stipulated that agricultural land that had originally been used for mining purposes was to be recultivated as agricultural land, without exception. However, after 1989, the situation shifted to the opposite extreme. Owing to the de facto collapse of the socialist agricultural planning system, recultivation of mining sites as agricultural land was abandoned, and most sites underwent systematic afforestation (Martinec et al., 2006).

By the beginning of the 1980s, woodland covered 4,651 ha of the Karviná district (13.39\%), mainly because of recultivation. However, from the perspective of landscape structure, the new woodlands were only small (none of them exceeded $6 \mathrm{~km}^{2}$ ), and they were scattered over a wide area. At this point in time, the Karviná district had 250 separate woodland entities. Woodlands still covered a considerably lower than average percentage of the land - both in comparison with the North Moravia region (38\% woodland) and the whole of Czechoslovakia (35\%). This made Karviná one of the least wooded districts in the entire country (Plaček et al., 1984).

A substantial increase in the area of woodland in the Karviná district came after 1989. The rapid decline of the mining industry in the Ostrava-Karviná coalfield and the decision to quickly repair the damage caused to the landscape by former mining activity ushered in an era of large-scale recultivation. At the same time, the very rapid collapse of the socialist agricultural planning system led to a decline in agricultural land use, and some agricultural land became woodland; most frequently, woodland areas expanded into adjacent areas with scattered trees, scrub and grasses or into abandoned agricultural land, thus causing a process of partial afforestation. The increase in the area of woodland in the past three decades has been the most dynamic in the investigated history of the study area; woodland currently covers around 7,933 ha of the district (more than 22\% of its area), a historical maximum. The process of afforestation has affected $12 \%$ of the district's territory during this most recent period - mainly in the central part of the district, as a result of recultivation projects.

On the basis of the data gained from the maps, it is possible to trace not only the changes in the area of woodland as a proportion of the total land cover but also the spatial distribution of woodlands. In order to conduct a temporal-spatial analysis of the individual processes, a map was created for each period under investigation (1780-1836, 1836-1876, 1876-1952 and 1952-2017) showing the areas affected by the processes of afforestation and deforestation within the entire study area (Fig. 2). Table 2 presents the data in percentage. 
From the year 1780 to the year 1836

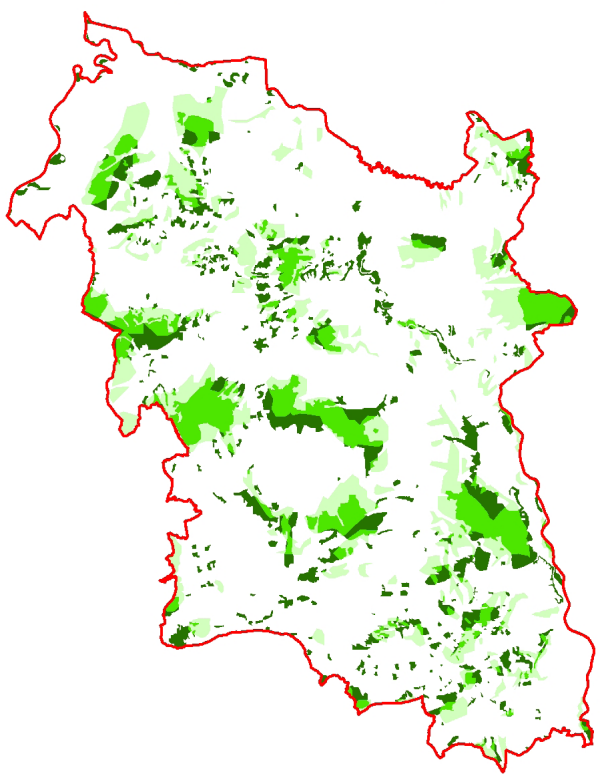

From the year 1876 to the year 1952

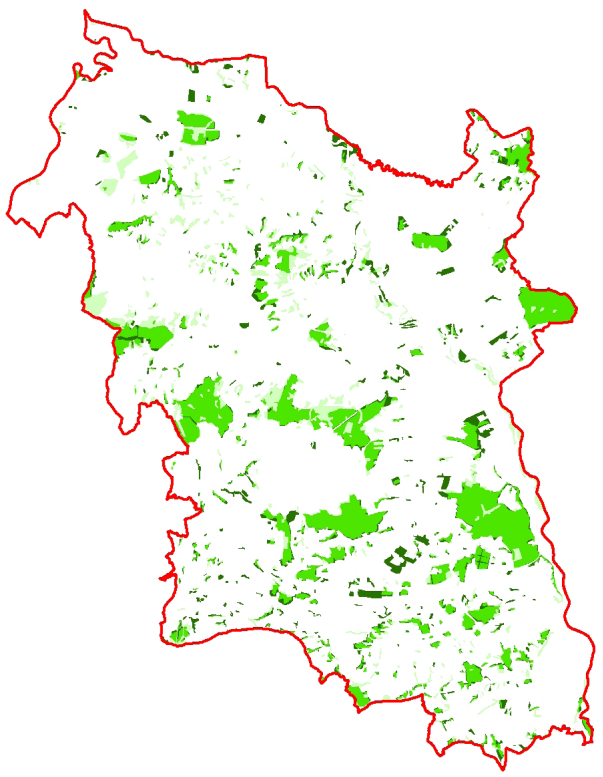

From the year 1836 to the year 1876

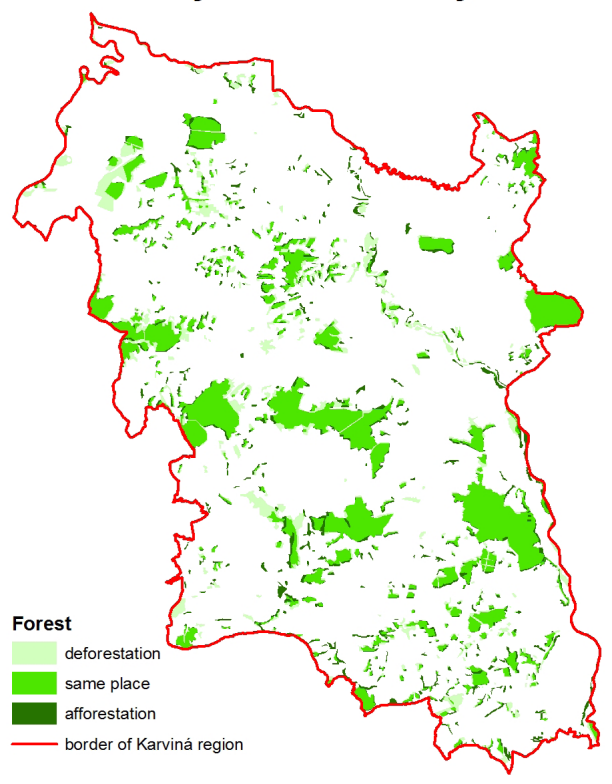

From the year 1952 to the year 2017

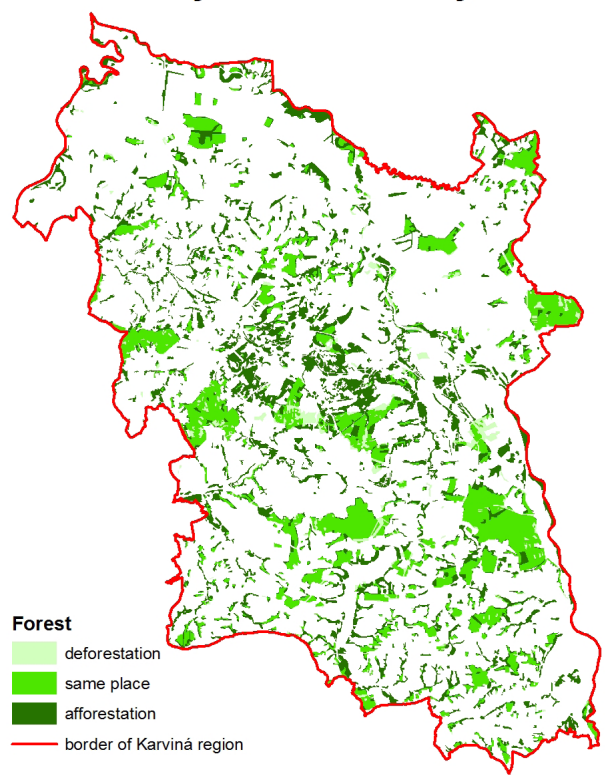

Fig. 2. Woodlands undergoing no change and afforestation/deforestation processes in Karviná district during the years $1780-2017$. 
$\mathrm{T}$ a b l e 2. Percentage of the total area of the Karviná district undergoing all types of afforestation/deforestation processes (and woodlands undergoing no change) during the years 1780-2017.

\begin{tabular}{|l|c|c|c|c|}
\hline \multirow{2}{*}{\multicolumn{1}{|c|}{ Process }} & \multicolumn{4}{|c|}{ Area (\% from the total area) in the period } \\
\cline { 2 - 5 } & $\mathbf{1 7 8 0}-\mathbf{1 8 3 6}$ & $\mathbf{1 8 3 6}-\mathbf{1 8 7 6}$ & $\mathbf{1 8 7 6}-\mathbf{1 9 5 2}$ & $\mathbf{1 9 5 2 - 2 0 1 7}$ \\
\hline afforestation & 7.86 & 3.07 & 3.10 & 12.04 \\
\hline deforestation & 11.79 & 4.50 & 4.65 & 1.99 \\
\hline no change & 7.34 & 10.70 & 9.12 & 10.23 \\
\hline
\end{tabular}

On the basis of a multitemporal data analysis, it is possible to identify the locations at which woodlands were present throughout the entire investigated period. A total of 1,413 ha (4\% of the territory of the Karviná district) remained as woodland throughout this period. Two-fifths of the woodland identified from the initial data (the first series of military maps) remained intact throughout the entire period. From the perspective of landscape change, some of these woodland areas are of considerable importance for both biodiversity and ecostability. Some of the areas have been granted legal protection in recognition of this fact, whilst others are only now being researched.

One such area is the Černý Les wood in Karviná-Ráj. This is a complex of woodlands located on the north-west slopes of the Ráj hill, which is bisected by the Czech-Polish border. The area has remained intact partly because it was used by the military before 1989 and was thus off-limits to the general public. It consists of indigenous deciduous species, including some rare examples of the European beech and the European spindle.

A similar area, with stable and high-quality populations of indigenous species, is the Krajčok wood in the cadastral area of Orlová. The wood is now used for recreational purposes. It includes 12 protected trees representing the original deciduous populations: 8 European beeches, 2 sessile oaks, 1 sycamore and 1 hornbeam (ages ranging from 110 to 250 years).

An example of natural riparian woodland in the study area is located near the village of Věřnovice, in the north of the Karviná district. The wood is part of a legally protected area classified as a natural monument, covering 4.59 ha and forming a near-natural community on a river terrace. Most of the protected area is riparian woodland, which, in the wetter parts, is dominated by elms and in the drier parts by oak/hornbeam populations. In places, the natural composition of the wood has been disrupted by plantings of non-indigenous species (e.g. the red oak and the European beech). However, large examples of indigenous trees have survived, including oak, ash, white elm, lime (linden) and field maple (Mackovčin, Sedláček, 2004). Adjacent to the protected area is the small Dembina wood (which appears in the maps from the second military series onwards) and meadows separated by avenues of trees. There are willow belts in the former beds of meanders, which, in some places, have been very well preserved. Some parts of the woodlands within the Verrnnovice natural monument are recorded as existing in the first half of the 19th century.

The only large legally protected area of woodland in the district is the Velké Doly nature reserve, which covers an area of 30.5 ha between the towns of Český Těšín and Třinec. The reserve consists of mixed woodland with lime (linden) and hornbeam populations and several protected plant species. The original oak and beech populations were destroyed in the 
18th century by limestone quarrying and replaced by hornbeam, lime (linden), field maple and sycamore. More than 40 bird species have been observed in the woodland (Mackovčin, Sedláček, 2004).

The Karviná district also has a number of interesting small-scale protected areas along several watercourses, which are bordered by small woodland areas. The natural monument 'Hraniční meandry Odry' (i.e. border meanders of the Odra River) is an 8-km section of the meandering Odra River running along the Czech-Polish border from the Odra/Olše confluence to the town of Starý Bohumín, plus the riparian woodlands adjacent to the river and both temporary and permanent bodies of standing water, and also the 'Meandry Dolní Odry' (i.e. lower Odra meanders), a Site of Community Importance (SCI) forming part of the Natura 2000 system (Mackovčin, Sedláček, 2004). The natural monument also includes Vrbina, a periodically submerged part of the riparian woodland. Common mergansers nest in the old hollow trunks of the black poplars and willows. At some locations adjacent to the Odra River in this natural monument, woodlands existed in the first half of the 19th century.

At south-western extremity of the Karviná district (on the outskirts of the city of Havírov) is the site of the 'Meandry Lučiny' (Lučina meanders) natural monument. The main protected feature is the unregulated course of the Lučina River, which creates natural meanders in alluvial deposits several metres thick. In the vicinity is woodland with hackberry and ash or oak and hornbeam populations, with varied flora and fauna. Gravel terraces have been formed on the right bank of the river, which are home to marsh alder stands (Mackovčin, Sedláček, 2004).

\section{Discussion and conclusion}

The data sources - i.e. historical military maps - were chosen because of both the comparability of the map scales and the precision of the maps for military purposes (including details of woodland areas). The most recent orthophoto (2017) was used to capture the current situation; the data from the orthophoto was verified using current maps.

Owing to the fact that the first military mapping was conducted à la vue', not all the positions of the map elements are recorded with sufficient accuracy; therefore, the precise size and location of the woodland areas cannot be considered entirely accurate. However, this is the only relevant map source from the 18th century that can be used at least to give an approximate indication of the occurrence and extent of woodlands - not only in the study area (the Karviná district) but throughout the Bohemian Crown Lands. In the subsequent military maps, the situation is different; from the second series onwards, the mapping was based on prior astronomic and geodetic surveying. The data yielded by these maps are precise and suitable for a quantitative analysis of changes in woodland cover.

The depiction of woodland areas in the source maps makes it possible to trace primarily the quantitative changes in these areas and to identify processes of landscape change. With regard to qualitative changes (species composition, age, etc.), the maps are less useful. It is difficult to determine the changing distribution of individual types of woodland from the maps; either the predominant species is not marked at all (e.g. in the first series of military maps) or it is only given for the larger areas of woodland (the second series). However, the 
information on qualitative changes can be obtained from other types of archive materials or historical publications.

When comparing the current distribution of woodlands with the situation in the second half of the 18th century, we can observe a substantial increase in the total area covered by woodlands; this has occurred primarily during the past 50 years, following a long period that had been characterised by a long-term decrease. This basic trend is in line with the trends described in a study by Munteanu et al. (2014), but the Karviná district displays some specific features. In the 1780s, woodlands made up approximately $19 \%$ of the landscape in today's Karviná district. This indicates the intensive development of agriculture in the lowland areas of the district. Even at that time, woodlands in the district were widely dispersed. With regard to the age and species composition of the woodlands, historical materials provide information on the predominance of long-established mixed woodlands, consisting mainly of conifer species (especially fir) and partially also of deciduous species (especially beech, oak and alder).

By the 1830s, the first wave of deforestation had already taken place in the study area; this was in line with the general trend throughout the Bohemian Crown Lands. This first phase of the deforestation process was (surprisingly) the most intense deforestation of the entire investigated period - even if we take account of certain inaccuracies in the military maps. The need for new arable land, as well as the need to expand sheep farming, led to the clearance of much existing woodland. The subsequent phase of deforestation, essentially corresponding with the industrial era (from the 1830s to the 1970s), was characterised by a relatively slow yet constant reduction in woodland areas; the less-intensive process of afforestation was not able to compensate for the deforestation. Deforestation during this period was relatively slow because the area covered by woodland was relatively low from the outset of the industrialisation process. The total area of woodland indicated by the second series of military maps (15\%) is well below the average figure for the whole of the Bohemian Crown Lands, that is, $29 \%$ of their total area (Popelka et al., 2016: 51). By the 1970s, the long-term deforestation of the landscape in the Karviná district meant that (along with neighbouring Ostrava) it was one of the least forested districts in Czechoslovakia.

Some of the reasons for this deforestation were generally applicable to the entire country (such as the intensification of agriculture before 1945 and under the socialist planned economic system). Others, however, were connected with the specific features of the study area (deforestation as a result of coal mining, the influence of air pollution from industry, extensive construction work and the growth of new urban communities). The analysis showed that most woodlands in the Karviná district became arable land and were used for agricultural purposes; this is one of the paradoxes of the landscape changes that affected the Ostrava-Karviná coalfield, especially during the Cold War era.

The species composition of the woodland areas also changed. Firs practically disappeared during the second half of the 19th century, and only the more resilient deciduous populations remained (accompanied by spruce populations). During the second half of the 20th century, the pace of deforestation slowed considerably - a result of the rapid pace with which the process had occurred previously.

The early 1980s marked a turning point at which the predominant trends of the previous period began to change rapidly. The process of afforestation - which had previously been 
only a marginal feature in the Karviná district - became one of the most significant landscape change processes; this finding is in line with several existing studies (e.g. Plieninger, Bieling, 2012; Plieninger et al., 2016). Woodland areas began to expand - primarily into areas previously affected by the process of abandonment, where there were already scattered trees, scrub and grasses, as well as into abandoned agricultural land. The process of afforestation was also linked to the recultivation of former mining sites by new plantings (a method which became very widespread from the late 1980s) and the collapse of the socialist agricultural system.

The increase in the area of woodland during the past three decades has been the most dynamic in history. It has affected the entire study area - especially the central part of the Karviná district, where it is associated with large-scale recultivation work at former coal mining sites; afforestation has become the most widespread method of recultivation. Another factor is the more rigorous legal protection of the remaining original woodland biotopes, which represent an important source of ecostability in the region.

\section{References}

Antrop, M. \& Van Eetvelde V. (2000). Holistic aspects of suburban landscapes: visual image interpretation and landscape metrics. Landsc. Urban Plann., 50(1-3) 43-58. DOI: 10.1016/S0169-2046(00)00079-7.

Biopress (2016). Linking Pan-European land cover change to pressures on biodiversity. http://www.creaf.uab.es/ biopress/index $2 . \mathrm{htm}$

Boguszak, F. \& Císař J. (1961). Mapování a měření českých zemí od poloviny 18. století do počátku 20. století. Praha: Ústřední správa geodézie a kartografie.

Brůna, V., Buchta, I. \& Uhlířová L. (2003). Interpretace prvků mapy prvního a druhého vojenského mapování. Historická Geografie, 32, 93-114.

Brůna, V. \& Křováková K. (2006). Využití starých map středního a velkého měřítka pro sledování vývoje lesů. http:// bruna.geolab.cz/files/oldmaps/srni.pdf

Cooper, A. \& Loftus M. (1998). The application of multivariate land classification to vegetation survey in the Wicklow Mountains, Ireland. Plant Ecology, 135(2), 229-241. DOI: 10.1023/A:1009707211061.

Čada, V. (2006). Hodnocení polohové a geometrické přesnosti prvků II. Vojenského mapování lokalizovaných v S-JTSKHistorická krajina a mapové bohatství Česka. Historická Geografie, Suppl., 82-105.

Čapek, R. (1978). Dálkový průzkum a fotointerpretace z hlediska geografa. Praha: SNP.

Drlík, R. (1962). Poddolovaná území v Ostravsko-karvinském revíru. Uhlí, 4(12), 419-422.

Essex, S. \& Williams A. (1992). Ecological effects of afforestation: a case study of Burrator, Dartmoor. Applied Geography, 12, 361-379. DOI: 10.1016/0143-6228(92)90014-E.

Feranec, J., Hazeu, G., Christensen, S. \& Jaffrain G. (2007). Corine land cover change detection in Europe (case studies of the Netherlands and Slovakia). Land Use Policy, 24, 234-247. DOI: 10.1016/j.landusepol.2006.02.002.

Hauserová, M. \& Poláková J. (2015). Pomůcka pro používání základních historických map pro studenty FA ČVUT. Praha: ČVUT. http://pamatky- facvut.cz/download/dokumenty/pomucka.pdf

Havrlant, M. (1964). Zemédělství karvinského okresu. Sborník prací pedagogického institutu v Ostravě. Praha: Státní Pedagogické Nakladatelství.

Hersperger, A.M. \& Bürgi M. (2009). Going beyond landscape change description: Quantifying the importance of driving forces of landscape change in a Central Europe case study. Land Use Policy, 26, 640-648. DOI: 10.1016/j.landusepol.2008.08.015.

Korbelářová, I. (2005). Města na Těšínsku v 18. století. Český Těšín.

Kučera, T. \& Guth J. (1999). Stabilization of the natural landscape in the Bohemian Forest frontier area (Czech Republic/Germany) abandoned for 40 years. In Proceedings of the CZ-IALE conference Present and Historical Nature-Culture Interactions in Landscapes (Experiences for the 3rd Millennium) (pp. 183-190). Praha: Karolinum. 
Kuchař, K. (1967). Mapové prameny k geografii Československa. Acta Universitatis Carolinae, Geographica, 2, 57-97.

Lasanta, T., Arnáez, J., Pascual, N., Ruiz-Flano, P., Errea, M. P. \& Lana-Renault N. (2017). Space-time process and drivers of land abandonment in Europe. Catena, 149, 810-823. DOI: 10.1016/j.catena.2016.02.024.

Leitao, B., Miller, J., Ahern, J. \& McCarigal K. (2006). Measuring landscapes: A professional planner's manual. Washington: Island Press.

Lieskovský, J., Bezák, P., Špulerová, J., Lieskovský, T., Koleda, P., Dobrovodská, M., Burgi, M. \& Gimmi U. (2015). The abandonment of traditional agricultural landscape in Slovakia - Analysis of extent and driving forces. Journal of Rural Studies, 37, 75-84. DOI: 10.1016/j.jrurstud.2014.12.007.

Mackovčin, P. \& Sedláček M. (2004). Ostravsko. Chráněná území ČR. Svazek X. Praha: Agentura Ochrany Přírody a Krajiny.

Marcucci, D.J. (2000). Landscape history as a planning tool. Landsc. Urban Plann., 49, 67-81. DOI: 10.1016/ S0169-2046(00)00054-2.

Mareš, J. (Ed.) (1975). Vliv člověka na životní prostředí Ostravska. Brno: Geografický ústav ČSAV.

Martinec, P., Schejbalová, B., Hortvík, K. \& Maníček J. (2005). The effects of coal mining on the landscape of the Ostrava region. Moravian Geographical Reports, 13(2), 13-26.

Martinec, P. \& et al. (2006). Vliv ukončení hlubinné těžby uhlí na životní prostředí. Ostrava: Anagram.

Mikšovský, M. \& Zimová M. (2006) Müllerovo mapování a první vojenské mapování českých zemí (se zřetelem k digitalizaci a centrální evidenci map v Česku). Historická krajina a mapové bohatství Česka. Historická Geografie, Suppl., 14-23.

Mulková, M., Popelková, R. \& Popelka P. (2016) Black Land: The Mining Landscape of the Ostrava-Karviná Region. In T. Pánek. \& J. Hradecký (Eds.), Landscapes and Landforms of the Czech Republic. Springer International Publishing.

Munteanu, C., Kuemmerle, T., Boltižiar, M., Van Butsic, Gimmi, U., Halada, L., Kaim, D., Király, G., Konkoly-Gyuró, É., Kozak, J., Lieskovský, J., Mojses, M., Muller, D., Ostafin, K., Ostapowicz, K., Shandra, O., Štych, P., Walker, S. \& Radeloff V.C. (2014). Forest and agricultural land change in the Carpathian region. A meta-analysis of longterm patterns and drivers of change. Land Use Policy, 38, 685-697. DOI: 10.1016/j.landusepol.2014.01.012.

Myška, M. (1989). Průmyslová revoluce a proměny životního prostředí v ostravské aglomeraci. Časopis Slezského Muzea, 38(3B), 241-262.

Nožička, J. (1956). Z minulosti slezských lesů. Nástin jejich vývoje od nejstarších časů do $r$. 1914. Opava: Slezský Stud. Ústav.

Otahel, J. \& Feranec J. (1999). Landscape structure analysis in environmental planning: Case study - Part of Liptov (Slovakia). In Proceedings of the CZ-IALE conference Present and Historical Nature-Culture Interactions in Landscapes (Experiences for the 3rd Millennium) (pp. 155-169). Praha: Karolinum.

Pitronová, B. (1968). Těšinské Beskydy na sklonku feudalismu. Salašnictví a lesní hospodářství v Těšínských Beskydech na přelomu 18. a 19. století. Brno.

Plaček, V. \& et al. (1984). Okres Karviná. Ostrava: Profil.

Plieninger, T. (2006). Habitat loss, fragmentation, and alteration - Quantifying the impact of land-use changes on a Spanish dehesa landscapes by use of aerial photography and GIS. Landsc. Ecol., 21, 91-105, DOI: 10.1007/ s10980-005-8294-1.

Plieninger, T. \& Bieling C. (2012). Connecting cultural landscapes to resilience. In T. Plieninger \& C. Bieling (Eds.), Resilience and the Cultural Landscape. Understanding and Managing Change in Human-Shaped Environments (pp. 3-26). Cambridge: Cambridge University Press. DOI: 10.1017/CBO9781139107778.

Plieninger, T., Draux, H., Fagerholm, N., Bieling, C., Bürgi, M., Kizos, T., Kuemmerle, T., Primdahl, J. \& Verburg P.H. (2016). The driving forces of landscape change in Europe: A systematic review of the evidence. Land Use Policy, 57, 204-214. DOI: 10.1016/j.landusepol.2016.04.040.

Popelka, P. (2013). Nová krajina. Počátky rekultivace krajiny ostravsko-karvinského revíru (do konce 60 . let 20. století). Časopis Matice Moravské, 132, 445-476.

Popelka, P., Popelková, R. \& Mulková M. (2016). Black or green land? Industrialisation and Landscape Changes of the Ostrava-karviná Mining District in the 19th and 20th Century. Ostrava: FF OU.

Rodan, K. (2008). Dějiny zemědělství v Rakouském Slezsku v letech 1848-1914 (základní vývojové tendence). Ostrava: FF OU.

Rühl, J., Gristina, L., La Mantia, T., Novara, A. \& Pasta S. (2015). Afforestation and Reforestation: The Sicilian Case Study. In R. Valentini \& F. Miglietta (Eds.), The Greenhouse Gas Balance of Italy (pp. 173-184). Environmental Science and Engineering. Berlin, Heidelberg: Springer. 
Selby, A., Petäjistö, L. \& Koskela T. (2005). Forests and Afforestation in a Rural Development Context: a Comparative Study of three Regions in Finland. Helsinki: Finnish Forest Research Institute.http://www.metla.fi/julkaisut/workingpapers/2005/mwp014.pdf

Semotanová, E. (2001). Mapy Čech, Moravy a Slezska v zrcadlech staletí. Praha: LIBRI.

Sexton, J.O., Urban, D.L., Donohue, M.J. \& Song C. (2013). Long-term land cover dynamics by multi-temporal classification across the Landsat-5 record. Remote Sensing of Environment, 128, 246-258. DOI: 10.1016/j. rse.2012.10.010.

Sklenička, P. (2003). Základy krajinného plánování. Praha: Naděžda Skleničková.

Sleeter, B.M., Sohl, T.L., Loveland, T.R., Auch, R.F., Acevedo, W., Drummond, M.A., Sayler, K.L. \& Stehman S.V. (2013). Land-cover change in the conterminous United States from 1973 to 2000. Global Environmental Change, 23, 733-748. DOI: 10.1016/j.gloenvcha.2013.03.006.

Smolík, D. (1981). Výsledky lesnické rekultivace černouhelných odvalů v ostravsko-karvinském revíru. Uhlí, 29(5), 185-187.

Smolík, D. (1984). Vliv poklesů na kvalitativní změny hlavních genetických půdních typů v ostravsko-karvinském revíru. Uhlí, 32(2), 55-58.

Tichý, J. (1968). Původní lesy na Ostravsku a možnost pěstování dřevin. Př́rodovědecký Sborník, 24, 103-120.

Van der Zee, (1999). The use of GIC in the study of nature-culture interactions in landscapes. In P. Kovár (Ed.), Nature and culture in landscape ecology (Experiences for the $3^{\text {rd }}$ millennium). Praha: Karolinum.

Maps:

(๑) $1^{\text {st }}$ Military Survey, Section No. 6, 7, 8, 11, 12, 13, Austrian State Archive/Military Archive, Vienna, ๑ Laborator̆ geoinformatiky Univerzita J.E. Purkyně, @ Ministerstvo životního prostředí ČR

(C) $2^{\text {nd }}$ Military Survey, Section No. m020_O_4_X, m021_O_4_XI, m032_O_5_X, m033_O_5_XI, m047_O_6_X, m048_O_6_XI , Austrian State Archive/Military Archive, Vienna, () Laboratoř geoinformatiky Univerzita J.E. Purkyně, @ @ Ministerstvo životního prostředí ČR

(C $3^{\text {rd }}$ Military Survey, Section No. 4060_2, 4061_1, 4061_3, 4061_4, 4161_1, 4161_2, Austrian State Archive/Military Archive, Vienna, @ Laboratoř geoinformatiky Univerzita J.E. Purkyně, @ Ministerstvo životního prostředí ČR 
Appendix: Interpretation key.

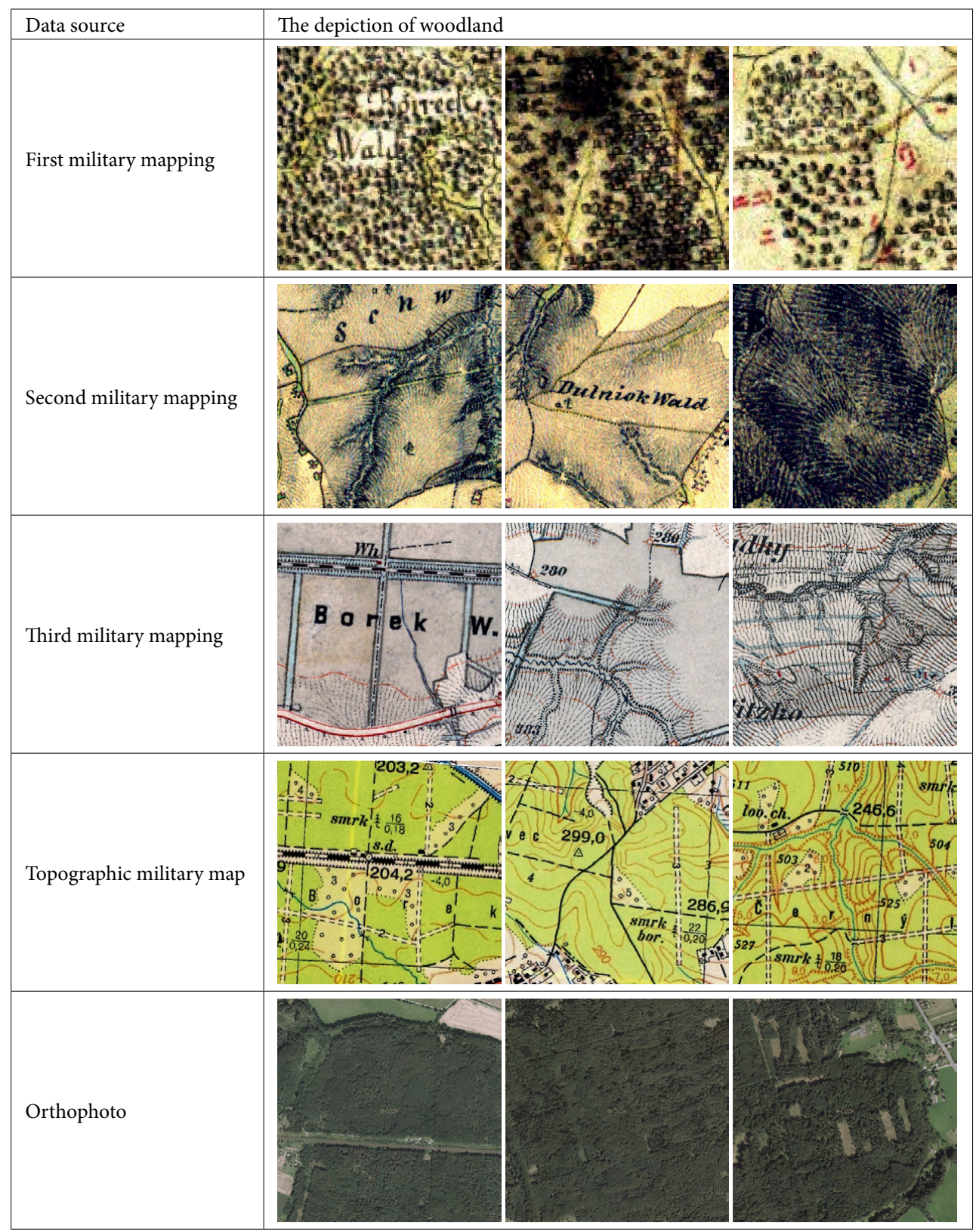

